DOI https://doi.org/10.18551/rjoas.2018-06.55

\title{
EFFECT OF VARIETY AND STICK INCLINATION ANGLE ON THE GROWTH, YIELD AND PHOTOSYNTHETIC EFFICIENCY OF SWEET POTATO (IPOMOEA BATATAS L.) IN THE PAPUA HIGHLANDS
}

\author{
Soplanit Alberth* \\ Graduate School of Agriculture, Faculty of Agriculture, University of Brawijaya \& \\ Indonesia/Papua Assessment Institute for Agricultural Technology, Indonesia \\ Guritno Bambang, Ariffin, Suminarti Nur Edy \\ Faculty of Agriculture, University of Brawijaya, Indonesia \\ *E-mail: asoplanit@yahoo.co.id
}

\begin{abstract}
Abiotic stress due to high levels of vulnerability in the Papua highlands is a deleterious limiting factor for the growth and development of sweet potato affecting yields. This study examined the effect of three varieties of sweet potato: Siate (narrow-leaves), Papua Sollosa (medium-leaves) and Cangkuang (broad-leaves) combined with four supporting stick angles - no stick and angles of $45^{\circ}, 60^{\circ}$ and $90^{\circ}$ - on the growth, yield and photosynthetic efficiency of sweet potato grown under field conditions. The results show that to optimize plant use of solar radiation in the highlands of Papua, it is advisable to use Cangkuang variety (broad leaves) combined with sticks angles of $60^{\circ}$ and $90^{\circ}$.
\end{abstract}

\section{KEY WORDS}

Sweet potato, variety, stick angles, Papua highlands, photosynthetic efficiency.

The island of Papua has a unique biodiversity and one example is in the Baliem valley, in the Papua highlands with sweet potato and pandanus sp. plants as the two main commodities that are best known to the wider community. Sweet potato plants known to local communities as "mother" plants or in local languages hipere, have special features because they are handed down through generations according to local agroecological conditions as well as unique cultivation techniques because they are intended not only as a source of food and fodder, but also for traditional ceremonies (Wydiastuti, 1994). Thus the existence of the local people known as Dani people is very dependent on the existence and availability of their sweet potato. La Achmady and Schneider (1993); Rauf and Lestari (2009) reported that local residents practice the cultivation of sweet potato in particular by separating varieties based on their designation. Varieties designated as foodstuffs usually have high starch content, an a dry and sweet taste while varieties with less palatable or tasty tubers, hight or low water content and high fiber content are intended as pig feed.

From generation to generation, local people have adapted the way of cultivating sweet potato in response to local climatic conditions. To overcome the limitation of sun radiation intensity, the Dani people have adopted local knowledge according to which they grow longvine cultivars which are wined around sticks of $120-150 \mathrm{~cm}$ in height aiming to prevent leaves from shading each other, while short-vine cultivars are grown on the edges of gardens (Widyastuti, 1994). This practice aims to enable plant leaves to get enough sunlight for photosynthetic and the crops to produce big tubers. The solar radiation in the Baliem valley generally starts at $10 \mathrm{am}$. Before this sunlight is blocked by fog caused by high levels of resistance, and at times the weather changes because suddenly the sun is blocked by clouds.

Soenarto (1997) and Saraswati et al. (2013) report that sun radiation intensity in the Baliem valley is only $1.38 \mathrm{~kJ} \mathrm{~cm}^{-2}$ day $^{-1}$ with an average duration of sunlight of around 4 hours day ${ }^{-1}$ because the weather is mostly cloudly. Sweet potato is a tropical plant that is intolerant to shade, both biotic and abiotic shade. As reported by Biswas et al. (1990) and 
Swadija et al. (2016) increasing the shade presentation from $0 \%-25 \%$ and increasing to $50 \%-75 \%$ can decrease the weight of fresh bulbs from $256.5 \mathrm{~g}$ to $110.2 \mathrm{~g}$ and the harvest index from 51.3 to 42.6. Shading of sweet potato can decrease the initiation of tuber formation, tuber number and tuber size (Osvald et al. (1995). Hozyo (1986) reported that to achieve maximum photosynthetic, all leaf strands should ideally receive normal sun exposure for 10 hours per day .

There has been much research on the practice of sweet potato cultivation in the highlands of Papua by various university researchers in Indonesia such as Widyastuti, 1994; Soenarto 1997; and Saraswati et al., 2013. However, the research is mostly focused on socio-cultural aspects and some agronomic and nutritional aspects of sweet potato, while agronomic and physiological responses of sweet potato plants to local climatic conditions, especially abiotic stress due to high level of resistance have never been investigated. For sweet potato to photosynthesize optimally and perform more efficiently in utilizing relatively low levels of solar radiation, cultivation improvements are needed to manipulate the plant environment by modifying the leaf angle so that more low level of solar radiation is intercepted by the plant canopy. One potential improvement is to combine the varieties with stick inclination angles of the right depth so as to increase the capture of solar radiation by plant leaves.

This study examines the ability of varieties with different leaf morphologies combined with sticks at different inclination angles to increase the efficiency of sweepotato utilizing sun radiation. The increase in the rate of efficiency in utilizing sun radiation by crops during their growing period can be measured through leaf number and dry weight characteristics, yield, and photosynthetic efficiency rates.

\section{MATERIALS AND METHODS OF RESEARCH}

Fieldwork was conducted at Wesakin, Wouma District, Jayawijaya Regency, Papua, Indonesia $\left(138^{\circ} .57^{\prime} \mathrm{BT}, 04^{\circ} \mathrm{04}\right.$ ' LS, $1.550 \mathrm{~m}$ asl) during the planting season from April to September 2016. Trial sweet potato crops were grown on dryland with alluvial soil which has a sandy loam texture and soil pH of 5.2. This trial used three sweet potato varieties: Siate (narrow-leaves), Papua Sollosa (medium-leaves) and Cangkuang (broad-leaves).

Table 1 - Sweet potato varieties used in the present study

\begin{tabular}{cccc}
\hline Variety & Stem length $(\mathrm{cm})$ & Leaf color & Leaf form \\
\hline $\begin{array}{c}\text { Siate } \\
\text { (narrow leaves) }\end{array}$ & $150-250$ & Green & Triangular \\
\hline $\begin{array}{c}\text { Papua Sollosa } \\
\text { (medium leaves) }\end{array}$ & $120-150$ & Green & Hastate \\
\hline $\begin{array}{c}\text { Cangkuang } \\
\text { (broad leaves) }\end{array}$ & $120-150$ & Green & Cordate \\
\hline
\end{tabular}

The treatments were laid out in a randomized block design in three replications. The three varieties were combined with four different sticks inclination angles: no stick and stick inclination angles of $45^{\circ}, 60^{\circ}$, and $90^{\circ}$, so that there were 12 combinations of treatments. Soil processing was done by means of shovels to cultivate the soil. The plot was divided into three groups and each group was divided into $5.25 \mathrm{~m} \times 6.50 \mathrm{~m}$ plots. The distance between the groups was $100 \mathrm{~cm}$ and the distance between plots was $50 \mathrm{~cm}$, spacing $75 \times 50 \mathrm{~cm}$, one cutting planted per hole with single ridges. Weeding was done 15, 45 and 80 days after planting (DAP). Neither chemical fertilizer nor control of pests and diseases were applied in this experiment in accordance with the local government prohibitions. Observation were conducted using a destrucive method by taking 2 non-edge plants as samples 40, 70, 100 and 130 DAP. These samples were taken using a local wooden stick called a sege in the local language. Sun radiation interception was also measured using a lux meter (LX 1330 B). 
Measurement were done three times on and under the leaf canopy, and also three times on the surface of the soil at $11.00 \mathrm{AM}$ when the weather was bright. Sun radiation data was also collected from a local meteorological station (Class III Wamena).

The observation variables included Leaf number, Total dry weight, Tuber number per plant, Marketable tubers, Tuber yield, and Photosynthetic Efficiency $(E \mu)$. Leaf number was all completely opened leaves on the two plant sample. Total sweet potato were counted for every plot and divided by the total number of plants during the harvesting season and Photosynthetic Efficiency (E $\mu$ ) was measured using the Yoshida (1981) method. Plants were separated into root, stem, leaf and tuber, and then dried in an oven $80^{\circ}$ until reached constant weight. Total yield per hectare was calculated using the equation: Yield $\left(\mathrm{t} \mathrm{ha}^{-1}\right)=$ [(10000/scale of sampling plot)xyield of sampling plot] Finaly, the Photosynthetic efficiency $(\mathrm{E} \mu)$ was measured based on the total dry weight $\left(\mathrm{g} \mathrm{m}^{-2}\right)$ divided by solar radiation accumulative $\left(\mathrm{cal}^{-2} \mathrm{~cm}^{-2}\right.$ days $\left.{ }^{-1}\right)$ after harvesting.

Analyses of variance were carried out using GenStat 18 statistical software. The difference between treatments was tested using the least significant differences (LSDs) test at $5 \%$ probability level.

\section{RESULTS AND DISCUSSION}

Leaf Number. The number of leaves increased in all treatment combinations following the development of the plant and reached maximum in the treatment combining Siate variety with with no stick at 100 DAP. Leaf number of this combination then decreased at 130 DAP until the harvest. The lowest leaf count was obtained in the combination of Siate variety and $90^{\circ}$ angle, this was because some leaves became dry and this was not offset by the appearance of new shoots. Leaf position perpendicular to the leaf morphology is relatively small, allowing all leaves to be exposed to solar radiation resulting in a sharp increase in temperature around the leaves beyond the tolerance limit, consequently many leaves dried out. This is in accordance with the report on green leaf duration in wheat plants (Naruoke et al., 2012), which concludes that elevated temperature conditions above the threshold tolerance limit accelerate leaf aging.

Table 2 - Effect of combinations of varieties and stick angles on the leaf number at four times of observation (means of three replications)

\begin{tabular}{lllll}
\hline \multirow{2}{*}{ Combination varietyand stick angles } & \multicolumn{4}{l}{ Average leaf number at days after planting (DAP) } \\
\cline { 2 - 5 } & 40 & 70 & 100 & 130 \\
\hline P1 (Siate without stick) & $25.7 \mathrm{def}$ & $180.0 \mathrm{~d}$ & $213.5 \mathrm{f}$ & $182.5 \mathrm{~g}$ \\
P2 (Siate + stick angle of $\left.45^{\circ}\right)$ & $34.7 \mathrm{~g}$ & $115.3 \mathrm{a}$ & $157.5 \mathrm{abc}$ & $153.5 \mathrm{ef}$ \\
P3 (Siate + stick angle of $\left.60^{\circ}\right)$ & $28.0 \mathrm{ef}$ & $179.8 \mathrm{~d}$ & $200.7 \mathrm{ef}$ & $151.7 \mathrm{ef}$ \\
P4 (Siate + stick angle of $\left.90^{\circ}\right)$ & $31.7 \mathrm{fg}$ & $138.5 \mathrm{abc}$ & $181.7 \mathrm{cde}$ & $89.3 \mathrm{a}$ \\
P5 (P.Sollosa without stick) & $22.2 \mathrm{cde}$ & $132.5 \mathrm{abc}$ & $170.7 \mathrm{~cd}$ & $167.0 \mathrm{fg}$ \\
P6 (P.Sollosa + stick angle of $\left.45^{\circ}\right)$ & $12.7 \mathrm{a}$ & $158.0 \mathrm{~cd}$ & $205.0 \mathrm{ef}$ & $132.7 \mathrm{~cd}$ \\
P7 (P.Sollosa + stick angle of $\left.60^{\circ}\right)$ & $13.5 \mathrm{a}$ & $134.7 \mathrm{abc}$ & $180.0 \mathrm{cde}$ & $128.2 \mathrm{bc}$ \\
P8 (P.Sollosa + stick angle of $\left.90^{\circ}\right)$ & $15.7 \mathrm{ab}$ & $131.7 \mathrm{abc}$ & $165.5 \mathrm{bc}$ & $140.2 \mathrm{cde}$ \\
P9 (Cangkuang without stick) & $14.0 \mathrm{a}$ & $148.8 \mathrm{abc}$ & $194.7 \mathrm{def}$ & $212.2 \mathrm{~h}$ \\
P10 (Cangkuang + stick angle of $\left.45^{\circ}\right)$ & $20.5 \mathrm{bcd}$ & $139.3 \mathrm{abc}$ & $155.7 \mathrm{abc}$ & $124.5 \mathrm{bc}$ \\
P11 (Cangkuang + stick angle of $\left.60^{\circ}\right)$ & $16.7 \mathrm{abc}$ & $123.3 \mathrm{ab}$ & $132.8 \mathrm{a}$ & $113.2 \mathrm{~b}$ \\
P12 (Cangkuang + stick angle of $\left.90^{\circ}\right)$ & $11.0 \mathrm{a}$ & $113.0 \mathrm{a}$ & $144.3 \mathrm{ab}$ & $150.2 \mathrm{def}$ \\
\hline LSD 5\% & 6.1 & 29.4 & 28.2 & 18.4 \\
\hline
\end{tabular}

Notes: numbers with different letters in the same column shows significant difference in $L S D$ test $(P<0.05)$.

Plant dry weight. Treatments combining varieties and stick angles showed significant differences total plant dry weight in all growth phases except the vegetative phase at 40 DAP (Table 3). The highest total dry weights were obtained with the combination of Cangkuang variety and the inclination angles of $90^{\circ}, 60^{\circ}$ and $45^{\circ}$ at 130 DAP of $326.9,283.5$ and $261.1 \mathrm{~g}$ plant $^{-1}$ respectively (Table 3 ). The morphology of the leaves of the Cangkuang variety, which are relatively larger combined with the increasing stick inclination angle, greatly affected the ability of each leaf to capture incoming solar radiation. These results may suggest that the 
intensity of solar radiation is a dominant factor in increasing the production of biomass and affecting the activity of metabolic and plant genetic properties. Gifford et al. (1984) and Adeboye et al. (2016) states that under field conditions, plant development depends on the capacity of the canopy to capture the incident radiation and turn it into new biomass. The amount of intercepted radiation depends on leaf area index ( $\mathrm{LAl}$ ) and canopy orientation. Plenet et al. (2000) concluded that the photosynthetically active radiation (PAR) absorbed by the canopy depends on the LAl and the arrangement of plant leaves.

Table 3 - The average dry weight of the plants for various combinations of varieties and stick angles at the four times of observations (means of three replications)

\begin{tabular}{lllll}
\hline \multirow{2}{*}{ Combination of variety and stick angles } & \multicolumn{5}{c}{ Total dry weight $\left(\mathrm{g} \mathrm{plants}^{-1}\right.$ ) at days after planting (DAP) } \\
\cline { 2 - 5 } & 40 & 70 & 100 & 130 \\
\hline P1 (Siate without stick) & 6.5 & $19.6 \mathrm{a}$ & $52.5 \mathrm{a}$ & $79.9 \mathrm{a}$ \\
P2 (Siate + stick angle of $\left.45^{\circ}\right)$ & 7.6 & $78.9 \mathrm{c}$ & $108.3 \mathrm{~cd}$ & $137.2 \mathrm{~b}$ \\
P3 (Siate + stick angle of $\left.60^{\circ}\right)$ & 5.9 & $79.2 \mathrm{C}$ & $118.7 \mathrm{cde}$ & $174.7 \mathrm{~cd}$ \\
P4 (Siate + stick angle of $\left.90^{\circ}\right)$ & 5.6 & $55,3 \mathrm{~b}$ & $91.3 \mathrm{~b}$ & $102.9 \mathrm{a}$ \\
P5 (P.Sollosa without stick) & 5.6 & $47.6 \mathrm{~b}$ & $105.7 \mathrm{c}$ & $147.8 \mathrm{bc}$ \\
P6 (P.Sollosa + stick angle of $\left.45^{\circ}\right)$ & 5.4 & $56.2 \mathrm{~b}$ & $121.4 \mathrm{de}$ & $221.1 \mathrm{e}$ \\
P7 (P.Sollosa + stick angle of $\left.60^{\circ}\right)$ & 6.0 & $60.1 \mathrm{~b}$ & $129.7 \mathrm{e}$ & $227.3 \mathrm{ef}$ \\
P8 (P.Sollosa + stick angle of $\left.90^{\circ}\right)$ & 6.0 & $47.1 \mathrm{~b}$ & $89.3 \mathrm{~b}$ & $151.7 \mathrm{bc}$ \\
P9 (Cangkuang without stick) & 5.0 & $48.9 \mathrm{~b}$ & $117.1 \mathrm{cde}$ & $202.5 \mathrm{de}$ \\
P10 (Cangkuang + stick angle of $\left.45^{\circ}\right)$ & 5.9 & $94.5 \mathrm{~d}$ & $177.6 \mathrm{f}$ & $261.1 \mathrm{fg}$ \\
P11 (Cangkuang + stick angle of $\left.60^{\circ}\right)$ & 5.4 & $101.9 \mathrm{~d}$ & $184.4 \mathrm{f}$ & $283.5 \mathrm{~g}$ \\
P12 (Cangkuang + stick angle of $\left.90^{\circ}\right)$ & 4.9 & $105.1 \mathrm{~d}$ & $229.5 \mathrm{~g}$ & $326.9 \mathrm{~h}$ \\
\hline LSD 5 \% & Ns & 6.4 & 13.6 & 33.8 \\
\hline
\end{tabular}

Notes: numbers with different letters in the same column show significant difference in LSD test $(P<0.05)$; $D A P=$ days after planting; $n s=$ Not significant.

Tuber yield. Parameters used to present the results are number of tubers, proportion of marketable tubers, and tuber yield (Table 4 and Figure 1a). Low irradiation conditions in the Baliem Valley of the highlands of Papua mean that combinations of varieties with a more efficient stratum for capturing solar radiation produce better, as shown by the greater number of tubers for plants grown with sticks than for varieties without the use of sticks (Table 4). Similarly, the proportion of marketable tubers tended to be higher in combination of varieties using stick angles. This result is in accordance with the opinion of Maryasa (1990) that the use of artificial plants supports can capture sunlight more efficiently. Furthermore, Alkaumper and Midmore (1995) states that the shading of sweet potato reduces the initiation of tuber formation, the number of tubers and the size of the tubers.

Table 4 - Average tuber number and percentage of marketable tubers of harvested plants for various combinations of varieties and stick angles (means of three replications)

\begin{tabular}{|c|c|c|}
\hline \multirow{2}{*}{ Combination variety and stick angles } & \multicolumn{2}{|c|}{ Average tuber number per plant at harvest time } \\
\hline & Tuber number (plant ${ }^{-1}$ ) & Marketable tuber (\%) \\
\hline P1 (Siate without stick) & $2.36 \mathrm{ab}$ & $33.53 \mathrm{a}$ \\
\hline P2 (Siate + stick angle of $\left.45^{\circ}\right)$ & $3.83 \mathrm{~d}$ & $48.83 \mathrm{bcd}$ \\
\hline $\mathrm{P} 3\left(\right.$ Siate + stick angle of $\left.60^{\circ}\right)$ & $2.70 \mathrm{abc}$ & $53.67 \mathrm{~cd}$ \\
\hline $\mathrm{P} 4\left(\right.$ Siate + stick angle of $\left.90^{\circ}\right)$ & $2.00 \mathrm{a}$ & $35.07 \mathrm{a}$ \\
\hline P5 (P.Sollosa without stick) & $2.16 \mathrm{a}$ & $34.07 \mathrm{a}$ \\
\hline P6 (P.Sollosa + stick angle of $\left.45^{\circ}\right)$ & $3.36 \mathrm{~cd}$ & $42.10 \mathrm{ab}$ \\
\hline P7 (P.Sollosa + stick angle of $\left.60^{\circ}\right)$ & $3.53 \mathrm{~cd}$ & $48.27 \mathrm{bc}$ \\
\hline P8 (P.Sollosa + stick angle of $\left.90^{\circ}\right)$ & $3.26 \mathrm{bcd}$ & $33.57 \mathrm{a}$ \\
\hline P9 (Cangkuang without stick) & $3.16 \mathrm{bcd}$ & 41.97ab \\
\hline P10 (Cangkuang + stick angle of $\left.45^{\circ}\right)$ & $3.90 \mathrm{~d}$ & $59.33 \mathrm{~d}$ \\
\hline P11 (Cangkuang + stick angle of $60^{\circ}$ ) & $3.60 \mathrm{~cd}$ & $51.30 \mathrm{bcd}$ \\
\hline P12 (Cangkuang + stick angle of $\left.90^{\circ}\right)$ & $4.67 \mathrm{~d}$ & $56.40 \mathrm{~cd}$ \\
\hline LSD $5 \%$ & 0.9 & 10.7 \\
\hline
\end{tabular}

Notes: numbers with different letters in the same column shows significant difference in LSD test $(P<0.05)$. 


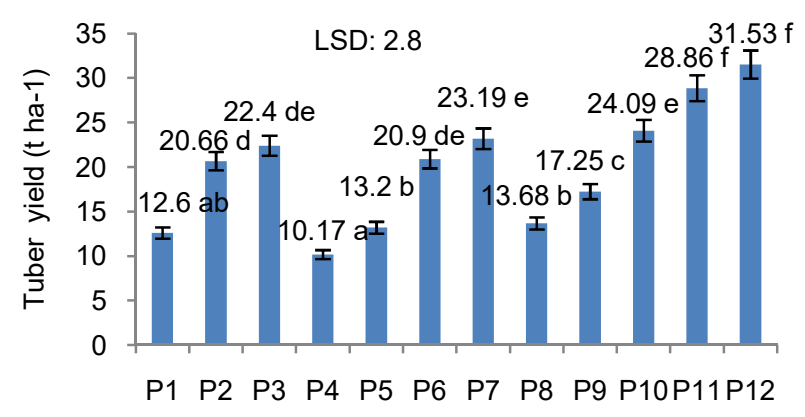

(a)

Treatment

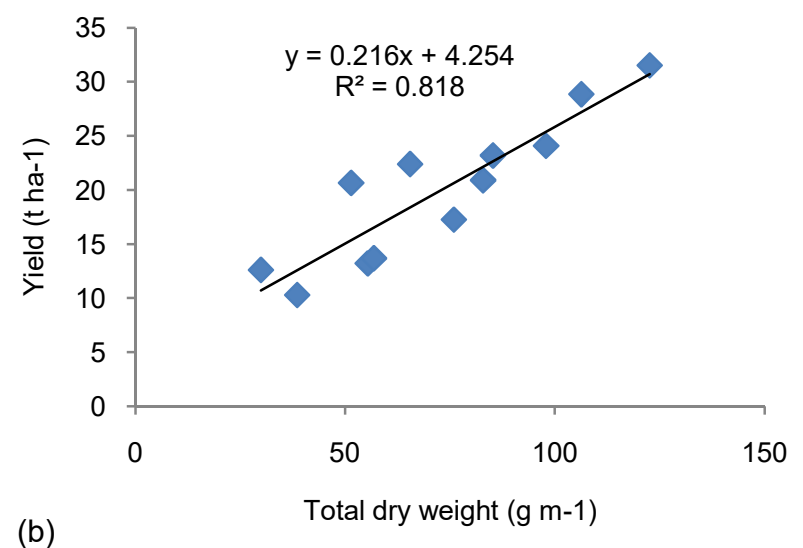

Figure 1 - The effect of combination of varieties and sticks angles on tuber yield ha ${ }^{-1}(a)$ and the relationship between total dry weight and tuber yields per hectare, with linear equation $y=0.216 x+4.254, R^{2}=0.818(b)$

Combination of varieties and stick angles affected the yield of tubers. The highest yield of tuber was obtained for the combination of Cangkuang variety with a $90^{\circ}$ stick angle (P12), followed by the same variety and an angle of $60^{\circ}(\mathrm{P} 11)$ with yields of $31.53 \mathrm{tha}^{-1}$ and $28.86 \mathrm{t}$ ha $^{-1}$ respectively, while the lowest tuber yields were obtained for the combinations of Siate without a stick and stick angle of $90^{\circ}$ (Fig. 1a). It is seen that the combination of varieties of sweet potato especially broad-leaved varieties with increasingly increased stick angles leads to more vertical leaf position and in low sunlight conditions allows most leaf sheets to capture light for photosynthetic. The treatments comprising varieties without the use of sticks caused the position of the leaves to overlap so that the effect was of mutual shade between the leaves and only the upper layer of leaf sheets can receive maximum light. The leaves on the bottom layer experienced lack of light because of shade and this had an impact on the low photosynthetic results. The low yield for the sweet potato on the combinations of Siate and Papua Sollosa cultivars with $90^{\circ}$ stick angles was caused because some of the leaves became the agent of photosynthetic aging which was not compensated by the emergence of new shoots. The result of a regression analysis showed that when the total dry weight of plants $(x)$ was higher the yield of tubers $(y)$ also increased. This is shown in the following linear equation: $y=0.216 x+4.254,\left(R^{2}=0.895\right)$, which shows that $90 \%$ of tuber yield can be explained by this equation model (Figure 1b). This means that the total dry weight of the plant plays an important role in increasing tuber yield of sweet potato.

Interception of solar radiation (Ei) and photosynthetic efficiency $(E \mu)$. The sweet potato planted in the highlands of Papua experiencing an average intensity over 130 days of 137.98 cal $\mathrm{cm}^{-2}$ days $^{-1}$ (data not shown) resulted in photosynthetic efficiencies $(\mathrm{E} \mu)$ of $0.57-2.06 \%$. The highest $E \mu$ values of $2.06 \%$ and $1.89 \%$ were obtained for a combination of Cangkuang and stick angles of $90^{\circ}$ and $60^{\circ}$ respectively. The lowest $E \mu$ of by $0.57 \%$ value was obtained in the treatment a combination of Siate variety with an angle of $90^{\circ}$ (P4) (Fig. 2a). The results for the highest $E \mu$ calculations in this study are similar to and even slightly higher than the 
findings of photosynthetic efficiency for tuber crops by Rana and Rana (2014) of $1.6-1.9 \%$. The results showed that the value of photosynthetic efficiency was increased in all treatment combinations except the combination of Siate and Papua Sollosa varieties with an angle of $90^{\circ}$.

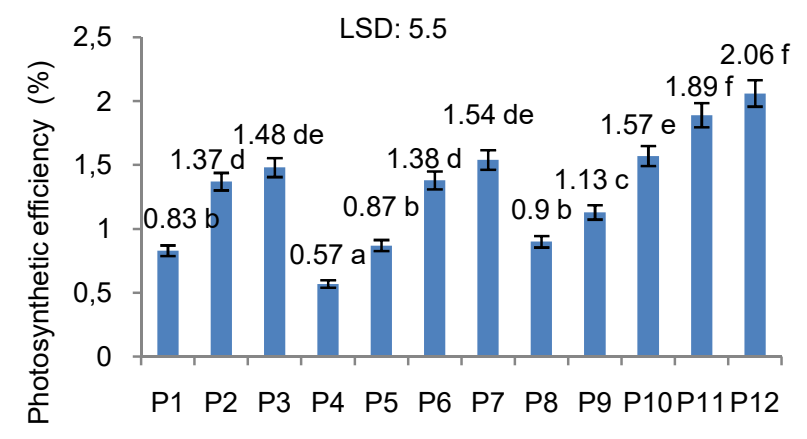

(a)

Treatment

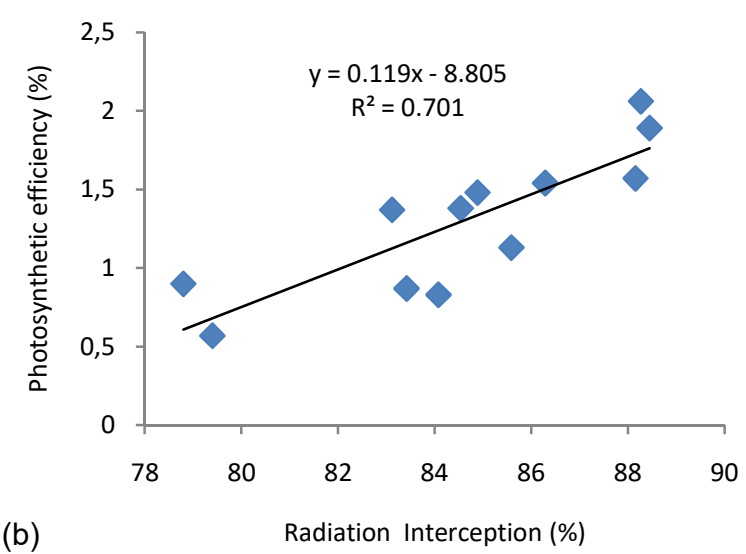

Figure 2 - The effect of combination of varieties and sticks angles on photosynthetic efficiency (a) and the relationship between Radiation Interception and photosynthetic efficiency, with linear equation $y=0.119 x+8.805, R^{2}=0.701(b)$.

This results could indicate that the combination of wide-leaved varieties with increasingly vertical angle orientation increases $\mathrm{E} \mu$ value, and PAR intercepted by individual leaves in each canopy layer. This is evidenced by the result of a regression analysis between solar radiation interception and photosynthetic efficiency which shows a linear relationship $y=0.119 x-8.805 R^{2}=0.701$ (Figure $2 b$ ), indicating that sun radiation interception plays an important role in increasing $E \mu$ value. Thus it can be concluded that the interception and use of solar radiation is influenced by genetic factors and plant environment as well as both affecting each other. Goudriaan (2016) states that the distribution of plant leaf corners plays an important role in determining the interception of light. Where there is no shortage of water and nutrients, the efficiency of solar radiation is determined by the interception of light, especially PAR by the canopy and the pattern of light distribution in the plant canopy (Monteith, 1977; Sitaniapessy, 1985; Russell et al., 1989; Tesfaye et al., 2006). Further Monsi and Saeki (1953) and Govindjee and Sharkey (2016) concluded that the leaf area index of the photosynthetic canopy will be maximized if the leaf is vertical.

\section{CONCLUSION}

Dry matter production increase is influenced by leaf number increase and the extent of the leaf area. Leaf morphology and the inclination angle interact with each other in increasing plant dry matter, tuber yield and photosynthetic efficiency of sweet potato. The morphological 
form of the leaf, i.e. varieties characterized by broad leaves truly influences the high efficiency of radiation interception causing enhancement of number of tubers and marketable tuber proportion. Separately, stick inclination angle influences the number of tubers per plant and marketable tuber proportion. Due to the low level of solar radiation intensity in the Papua highlands, varieties with broader leaves together with more vertical stick inclination angles interact with each other to increase the value of photosynthetic efficiency of solar radiation. Cangkuang variety with a wide leaf morphology achieved the highest production when it was combined with stick inclination angles of $90^{\circ}$ and $60^{\circ}\left(31.53 \mathrm{t} \mathrm{ha}^{-1}\right.$ and $28.86 \mathrm{t} \mathrm{ha}$ respectively). The combination of Cangkuang variety and a stick angle of $90^{\circ}$ resulted in the highest $\mathrm{E} \mu(2.06 \%)$ in contrast with $0.57 \%)$ for the combination of Siate variety without a stick.

\section{ACKNOWLEDGEMENTS}

This study was financially supported by the Indonesian Agriculture Research and Development Institute. Our appreciation also to the ACIAR/SARDI/CIP/AIAT of Papua project which was also provided some financial support.

\section{REFERENCES}

1. Adeboye. O.B, Bart Schultz, Kenneth O. Adekalu and Krishna Prasad (2016). Impact of water stress on radiation interception and radiation use efficiency of Soybeans (Glycine max L. Merr.) in Nigeria. Braz J. Sci. Technol (2016) 3:15.

2. Bidwell, R.G.S. 1979. Plant Physiology. Second Edition. Macmillian Publishing Co., Inc. New York. Caller Macmillian Publishers, London.P.38.

3. Fahrurrozi and K..A. Steward. 1994. Effect of mulch optical properties on weed growth and development. HorScience 29 (6): 545.

4. Gifford R.M, Thorne J.H, Hitz W.D, Giaquinta R.T (1984). Crop productivity and photoassimilate partitioning. Science 225:801-808.

5. Govindjee and Thomas D. Sharkey (2016). Advances in Photosynthesis and Respiration Including Bioenergy and Related Processes: Volume 42: Canopy Photosynthesis: From Basics to Applications. From the Series Editors: 364-377.

6. Hozyo, Y. 1982. Photosynthetic activity and carbon dioxide diffusion resistance as factors in plant production in sweet potato plants. Dalam Villareal, R.L and Griggs (ed.) Sweet potato, Proc., The First Int. Symp. AVDC.Taiwan China. 129 - 133.

7. Hozyo, Y.,M. Megawati and J.Wargiono. 1986. Plant production and potential productivity of sweet potato. Lap.Kem.Penel.Agron.Ubi-ubian Puslitbangtan 12:99-112.

8. La Achmady and J. Schneider. 1993. Sweet potato germplasm in the Jayawijaya division of Irian Jaya: diversity, problems and pathways on conservations. Workshop on Farm Conservation, 6-8 December, Bogor.

9. Monsi M., Saeki T. 1953. Ober den Lichtfaktor in den Pflanzengesellshaften und seine Bedeutung fir Stoffproduktion. Japanese Journal of Botany 14: 22-52.

10. Monteith, J.L. (1977). Climate and Efficiency of Crop Production in Britain. Philosophical Transactions of the Royal Society London B, 281, 277-294.

11. Maryasa, A. 1990. Pengaruh tinggi lanjaran dan waktu pemetikan sebagianpolong muda terhadap produksi dan viabilitas benih kacang panjang(Vigna sinensis (L.) Savi ex Hassk). Skripsi. Jurusan Budidaya Pertanian,Faperta, IPB. Bogor. 63 hal.

12. Naruoka, Y., J.D. Sherman, S.P. Lanning, N.K. Blake, J.M. Martin dan L.E. Talberth. 2012. Generic analysis of green leaf duration in spring wheat. Crop.Sci., 52:99-109.

13. Oswald, J., D.J. Alkaumper and I. Midmore, 1995a. Response of Sweet potato (Ipomoea batatas Lam.) to shading at different growth stages. Journal of Agronomy and Crop Science, 175: 99-107.

14. Plenet, D. A. Mollier, S. Pellerin (2000). Growth analysis of maize field crops under phosphorus deficiency. II. Radiation - use efficiency, biomass accumulation and yield components. Plant Soil 224:259-272. 
15. Russell, G., Jarvis, P.G., Monteith, J.L., 1989. Absorption of radiation by canopies and stand growth. In: Russell, G., Marshall, B., Jarvis, P.G. (Eds.), Plant Canopies: Their Growth, Form and Function. Cambridge University Press, Cambridge, pp. 21-40.

16. Rauf, A.W. dan M.S. Lestari. 2009. Pemanfaatan komoditas pangan lokal sebagai sumber pangan alternatif di Papua. Jurnal Litbang Pertanian, 28 (2): 54-62.

17. Rana, S.S. dan R.S. Rana. 2014. Advances in crop growth and productivity. Department of Agronomy, CSK HP Krishi Vishvavidyalaya, Palampur, India.

18. Sitaniapessy PM. 1985. Pengaruh jarak tanam dan besarnya populasi tanaman terhadap absorbsi radiasi surya dan produksi tanaman jagung (Zea mays L.) [disertasi]. Bogor: Institut Pertanian Bogor.

19. Soenarto, 1987. Wen Hipere suatu sistem budidaya ubijalar (Ipomoea batatas (L) (Lam) di Lembah Baliem, Irian Jaya. Institut pertanian Bogor. Fakultas Pascasarjana, Bogor. (tidak dipublikasikan).

20. Saraswati, P., A. Soplanit., A.T. Syahputra, L. Kossay, N. Muid, E. Ginting and G.Lyons. 2013. Yield trial and sensory evaluation of sweet potato cultivars in Highland Papua and West Papua Indonesia. Journal of Tropical Agriculture 51 (1-2): 74-83.

21. Tesfaye G, Sisay L, Dereje T, Abebe M and Solomon G. 2006. Growth and reproductive performance of central highland goats in North Shoa and South Wollo. Proceeding of the first annual conference on completed livestock research activity organized in Bahir Dar, Ethiopia, 14-17 August 2006, 7-13.

22. Swadija O. Komari, A. Jayapal and V.B. Padmanabhan, 2016. Abiotic Stress Physiology of Horticultural Crops. Tropical Tuber Crops, pp 343-368.

23. Wargiono, J. 1980. Ubijalar dan cara bercocok tanamnya. LPP. Bul. Tek. No.5. 37 hal.

24. Widyastuti, C.A. 1994. Peranan wanita suku dani dalam mempertahankan kelangsungan ubijalar sebagai makanan pokok di Kabupaten Jayawijaya, Irian Jaya. Dalam risalah seminar penerapan teknologi produksi dan pasca panen ubijalar mendukung agroindustri. Balai Penelitian Tanaman Pangan Malang.

25. Yoshida, S. 1981. Fumandamentalis of Rice Crop Science. P.1-110. IRRI, Los Banos, Philipines. 